\title{
KRIT1 wt Allele
}

National Cancer Institute

\section{Source}

National Cancer Institute. KRIT1 wt Allele. NCI Thesaurus. Code C52505.

Human KRIT1 wild-type allele is located within 7q21-q22 and is approximately $102 \mathrm{~kb}$ in length. This allele, which encodes Krev interaction trapped protein 1, may play a role in integrin signaling modulation. Mutations in the gene, which encode for products that terminate prematurely, are a factor in familial cerebral cavernous malformations. 